\title{
Current Scenario of Coronavirus Pandemic
}

\author{
Anshuman Mishra, ${ }^{1,2}$, Santanu Patra, ${ }^{1,2}$, Sudheesh K. Shukla², Pavan Pandey ${ }^{2}$, Yogesh Shukla ${ }^{2,3}$, \\ Pavel Osmera ${ }^{4}$, Pankaj Yadav 5 , Manoj Pandey ${ }^{5}$, Rajiv Gupta ${ }^{6}$, Franck Molina ${ }^{7}$, Carlos E. Semino ${ }^{8}$, \\ Ashutosh Tiwari ${ }^{1,2, *}$ \\ ${ }^{1}$ Institute of Advanced Materials, IAAM, Ulrika 59053, Sweden \\ ${ }^{2}$ VBRI, 7/16 Kalkaji Extn., New Delhi 110019, India \\ ${ }^{3} \mathrm{mH}$ Hospitals, 2/31, Nehru Enclave, New Delhi 110019, India \\ ${ }^{4}$ Institute of Automatization and Computer Science, Brno University of Technology, Brno 60190, Czech Republic \\ ${ }^{5}$ School of Technology, Pandit Deendayal Petroleum University, Gandhinagar 382007, India \\ ${ }^{6}$ Civil Engineering Department, Birla Institute of Technology and Science, Pilani 333031, India \\ ${ }^{7}$ Sys2Diag UMR9005 - CNRS/ ALCEDIAG, Montpellier 34184, France \\ ${ }^{8}$ Tissue Engineering Research Laboratory, Ramon Llull University, Barcelona 08017, Spain
}

*Corresponding author: E-mail: director@iaam.se; Tel.: (+46) 13312424

DOI: $10.5185 /$ amlett.2020.041494

World Health Organization (WHO) has expressed great concern about the pandemic of Coronavirus (COVID-19) and said that there is a need to control it at the high end. To strengthen this fight against COVID-19, International Association of Advanced Materials (IAAM) intends to provide a forum for high-tech healthcare. Foreseeing the current crisis, IAAM called a multi-lateral consortium to discuss the possibilities of developing a medical technology to control the spreading of coronavirus with the help of interdisciplinary experts from multiple countries. This innovation is perpetuated to create multi-lateral cooperation in the area of 'healthcare innovation and technology'. Adaptation of advanced technologies and their logical integration according to contemporary healthcare measures could be a smart strategy for epidemic management activities. Establishing an advanced phenotype model for prognosis is an important step in the prevention of infectious disease management such as COVID-19. This article has overviewed the global situation, efforts, and prospective of coronavirus pandemic.

\section{Introduction}

The worldwide threat of Coronaviruses (CoV) based epidemics and the latest outbreak in China created several complications in current healthcare practices in terms of prognosis and prevention. $\mathrm{CoV}$ have been, characterized by enveloped non-segmented positive-sense RNA viruses, which belong to the family Coronaviridae and the order Nidovirales, identified since the 1960's as a human pathogen [1]. The CoV pathogens are common in many different types of animals including camels, cats, cows, bats, horse, and human. In humans, till now seven types of coronaviruses have been reported, out of which four types (229E, NL63, OC43, and KHU1) are causing mild to moderate respiratory infections, like the common cold. Another two types, Severe Acute Respiratory Syndrome coronavirus (SARS-CoV) and Middle East Respiratory Syndrome coronavirus (MERS-CoV), can cause severe respiratory infections, while, the seventh type (Novel coronavirus or COVID-19) is a new coronavirus recently discovered in China [2]. In humans, COVID-19 cause illness mostly through respiratory or gastrointestinal infections, where symptoms can range from the common cold to more severe lower respiratory infections such as pneumonia [2]. Mainly person to person contact can impart more disease burden [3].
Human coronavirus outbreaks (SARS-CoV and MERS-CoV) have caused more than 10 thousand cumulative cases in the past two decades, with mortality rates of $10 \%$ for SARS-CoV and $37 \%$ for MERS-CoV [1] In general, different types of human coronaviruses vary in the severity of illness, their cause, and how far they can spread. Although drug repositioning and large spectra therapies are under evaluation, at present, no specific treatment is outlined for COVID-19. Risk of coronavirus outbreaks spread rapidly due to its ubiquitous presence and zoonotic mode of transmission through various host species [4], which makes it further complex pathogen.

Ideally, disease-associated biomarkers should be needed to identify infections with high sensitivity, specificity, reliability with rapidness and cost effectively to detect viruses. Studies related to immuno-sensing of bacteria or biomolecules and electrochemical biosensing of molecules through use of advanced material science have already established the biosensor research at next level $[\mathbf{5 , 6}$. Bioelectronic research on molecular switching through dynamic function leads towards possibility of advanced virus research, which can strengthen more efficiently to the prognosis strategies [7]. The gradual decline in the cost of sequencing genomes in trend studies, diagnostics, and real-time surveillance is helpful for rapid detection of disease outbreaks and understanding its mechanism. 


\section{Advanced Materials Letters www. vbripress.com/aml}

Digitalization due to advent of technologies will open opportunities for fast, accurate, distant diagnosis and delivery models. For mass level effectiveness, many precise wireless devices could be integrated to build the digital medicine type model for coronavirus [8]. Considering the recent technological advances, we have proposed to use an advanced technological model for better results. This model includes integration of latest technology of biosensors, Internet of things, and artificial intelligence (IoT and AI) along with clinical phenotype models for various $\mathrm{CoV}$ phenotypes (SARS-CoV, MERS-CoV, COVID-19, etc.). If coronavirus infections are not properly controlled, public health management will decline and global trades along with economy will suffer. This article deals with hosts' adaptability and pathogens variability to counterbalance the challenges against prognosis and preventive measures and produce a fundamental model to combat disease burden and viral infections in the scope of human health.

\section{Epidemics to pandemic journey}

Coronavirus' worldwide distribution and epidemiological parameters supporting pathogen-human interactions are responsible for infection. The epidemiology of COVID-19 major outbreaks is shown in Fig. 1. The four major outbreaks across the world are responsible for approximately more than 10 thousand mortalities [9-12]. It suggests that more than 30 thousand infections were diagnosed in the last two decades. Current COVID-19 epidemics break the geographical barrier and challenge the mass healthcare managements [11]. As data on 03 April 2020 , there are $1,026,974$ cases and 53,975 people have lost their lives [13]. The COVID-19 infection has caused clusters of severe respiratory illness similar to severe acute respiratory syndrome coronavirus and is associated with high mortality across the world $[\mathbf{1 2 , 1 3}]$. The major foci of COVID-19 have been in 21 countries having more than 5000 infections as of 03 April 2020. The major six countries, i.e., United States, Spain, Italy, Germany, China, and France belong to three different continents: Asia, Europe, and America respectively. The COVID-19 pandemic report shows these countries having more than 58,000 infected subjects. WHO has been assessing COVID-19 outbreak around the clock and as per observation, the number of cases outside China has increased about twelve-folds. The number of affected countries has increased eightfold as on 11 March 2020, and the situation was declared a pandemic. At that stage, $1,026,974$ cases were observed globally with a death count of 53,975 in 114 countries, where around 80 percent of cases were in just five countries and around 60 countries had reported 10 cases or less. After the declaration of pandemic, within 23 days as on 03 April 2020 [13,14], cases were about eight times and number of countries about four folds, i.e., a complete global spread of infection.

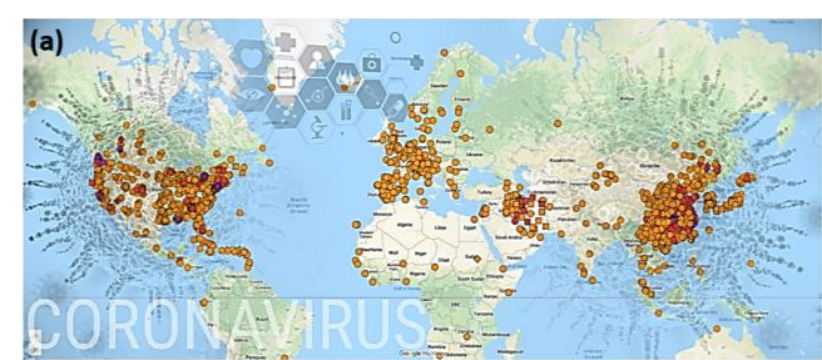

(b) $1250 \mathrm{k}$

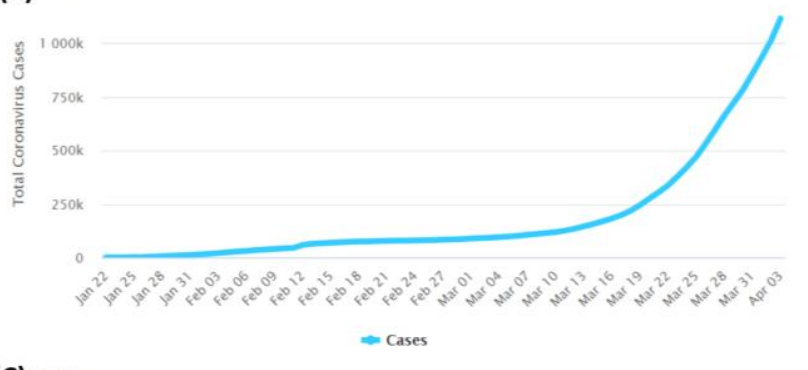

(C) $1250 \mathrm{k}$

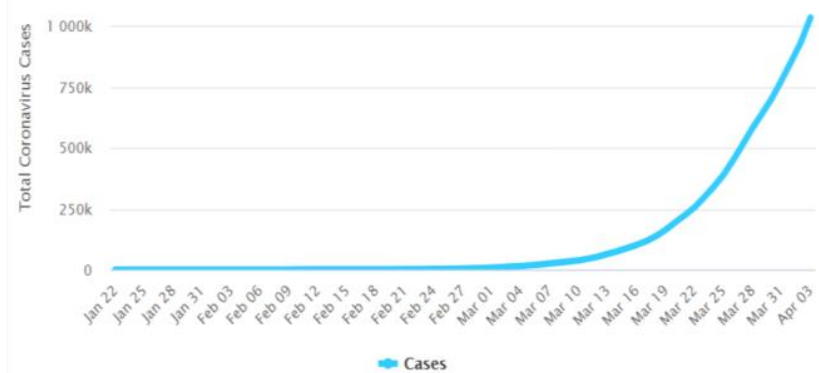

Fig. 1. (a) World map of COVID-19 pandemic, date wise (b) worldwide total cases and (c) total cases outside China as on 03 April 2020 [14].

Considering the current number of major foci, cases and deaths, declaration of pandemic situation is very timely and reasonable by $\mathrm{WHO}$ as this decision will alarm other countries and population to take preventive measures in advance. The 20 major foci having more than 5200 cases are shown in Table 1. It shows that Europe and North America are the epicenters of COVID-19, having major foci in Europe (Italy, Spain, Germany, France, etc.), America (USA, Canada, etc.) and East Asia (China, South Korea, etc.). Being world's biggest population center, any mismanagement in healthcare practices and control strategies can lead to massive outbreaks in several regions in South Asian countries such as India, Pakistan, Bangladesh, Sri Lanka, and Nepal. So as the $1^{\text {st }}$ step, connection between South Asian and other countries (China, Europe, America, etc.) should be cut at first instance at each label (populations, business products, food items, etc.). As the $2^{\text {nd }}$ step, research, technology and public healthcare related information should be exchanged thoroughly for effective disease control and preventive management.

The most adopted practice, social distancing through ban on international and local travels, and complete lockdown in big geographical area along with work from home model is the best strategy for isolation and stopping 


\section{Advanced Materials Letters www. vbripress.com/aml}

disease transmission. During epidemic to pandemic journey, various Asian countries of south and east regions (Japan, South Korea, Singapore, and India, etc.) have controlled the situation effectively till now. Adaptation of hygiene through technology, massive diagnosis and quarantine, complete lockdowns are the highlighted activities in these countries. There is an urgent need to understand their preventive public health models and adopt it as a policy.

Table 1. The epidemiology of COVID-19 major's outbreak (a) Top four major out breaks, (b) COVID-19 pandemic regions having more than 10,000 infection reported as on 03 April 2020*.

\begin{tabular}{|c|c|c|c|c|c|}
\hline \multicolumn{6}{|c|}{ Top four major out breaks } \\
\hline Year & Disease & $\begin{array}{l}\text { Country } \\
\text { and } \\
\text { Region }\end{array}$ & $\begin{array}{c}\text { Total } \\
\text { Infection }\end{array}$ & $\begin{array}{l}\text { Total } \\
\text { Death }\end{array}$ & Ref. \\
\hline 2003 & $\begin{array}{l}\text { Severe acute } \\
\text { respiratory } \\
\text { syndrome } \\
\text { coronavirus } \\
\text { (SARS-CoV) }\end{array}$ & $\begin{array}{l}\text { China and } \\
\text { Hongkong }\end{array}$ & 8096 & 774 & [9] \\
\hline 2012 & $\begin{array}{l}\text { Middle East } \\
\text { respiratory } \\
\text { syndrome } \\
\text { coronavirus } \\
\text { (MERS-CoV) }\end{array}$ & $\begin{array}{l}\text { Saudi Arab } \\
\text { and Middle } \\
\text { East }\end{array}$ & 2494 & 858 & [10] \\
\hline 2015 & $\begin{array}{l}\text { Middle East } \\
\text { respiratory } \\
\text { syndrome } \\
\text { coronavirus } \\
\text { (MERS-CoV) }\end{array}$ & $\begin{array}{l}\text { South } \\
\text { Korea and } \\
\text { China }\end{array}$ & 186 & 38 & [12] \\
\hline 2020 & $\begin{array}{l}\text { Novelcoronavirus } \\
(2019-\mathrm{nCoV})^{*}\end{array}$ & $\begin{array}{l}203 \\
\text { Countries }\end{array}$ & $1,026,974$ & 53,975 & [13] \\
\hline
\end{tabular}

COVID-19 pandemic regions having more than 10,000 infection

\begin{tabular}{llrr}
\hline S.No. & \multicolumn{1}{c}{ Country } & $\begin{array}{c}\text { Total } \\
\text { Infection }\end{array}$ & $\begin{array}{c}\text { Total } \\
\text { Death }\end{array}$ \\
\hline 1. & United States & 245,175 & 6,059 \\
2. & Spain & 117,710 & 10,935 \\
3. & Italy & 115,242 & 13,915 \\
4. & Germany & 85,269 & 1,111 \\
5. & China & 81,620 & 3,322 \\
6. & France & 58,441 & 5,380 \\
7. & Iran & 53,183 & 3,294 \\
8. & United Kingdom & 33,718 & 2,921 \\
9. & Switzerland & 19,106 & 565 \\
10. & Turkey & 18,135 & 356 \\
11 & Belgium & 16,770 & 1,143 \\
12. & Netherlands & 14,697 & 1,339 \\
13. & Canada & 11,268 & 138 \\
14. & Austria & 11,129 & 158 \\
15. & South Korea & 10,062 & 174 \\
\hline
\end{tabular}

* In 2020 COVID-19 outbreaks was pandemic with major foci having close to 10000+ infections data as on 03 April 2020 [13].

\section{Technologies for prognosis and preventive}

Use of the latest advancements of materials for sensor technology may be one of the appropriate leads towards virus detection from broad level. Studies based on nanoparticles, graphene, aptasensors, and ratiometric fluorescent have found to be effective for pathogen identification and their analysis $[\mathbf{1 5}, \mathbf{1 6}]$. The novel and interesting researches on functional genomics, quantitative genetics, genomic prediction, and epigenetics are helpful for understanding emerging disease, while additional environment-based studies were helpful in predict risks earlier $[\mathbf{1 7}, \mathbf{1 8}]$.

The development of artificial intelligence (AI)-based technologies in medicine has some practical issues in implementation related to clinical workflows, data sharing, privacy, transparency of algorithms, data standardization and interoperability across multiple platforms, which further have concern for patient safety [19]. Machine learning and deep learning are important analysis categories used in AI. IoT devices have become an essential part of the technology industry, as they can collect data and transfer it to research professionals via linked devices. Handling of data and inference of real meaning is quite challenging. The role of cloud computing is useful for gathering information, data exchange, connectivity and storage management.

Development of IT-based crowd management platforms for various markets, bus and train stations, airports, seaports will bring real-time monitoring of crowd for better control management. Registration of all the patients or subjects visiting hospitals through single mobile platform in the city by health authority. Through mobile phone sensing and being location/situation specific, we will get the information related to identical phenotypes together and monitoring them through coronavirus specific platform supports system. GIS Mapping and Spatial Analyses based health management will bring quick and flexible applications for advanced techniques.

The virus inactivation and filtration, by various strategies ( $\mathrm{pH}, \mathrm{UV}$, filters, etc.) is a robust and effective control measure [20-22], and needs further consideration as an important virus clearance technology. Material science and technology research will bring forth latest advancements in therapy and control strategies of virus. Digital technology for mass healthcare has become more affordable, cost effective, and easy to handle in health care practices $[\mathbf{2 3 , 2 4}$. Interestingly, digital medicine is poised to transform biomedical research, clinical practice and the commercial sector. Integration of all interdisciplinary technologies in single platform is the need of the hour [2024] for standard healthcare management for prevention and control of current COVID-19 [11]. All above advanced technologies were helpful to provide better solutions in prognosis and prevention of coronavirus epidemics and pandemic situation.

\section{COVID-19 tests}

WHO has recommended that all the countries should leave no stone unturned in the attempt to test their people for COVID-19 as much as possible. At this point, since no vaccine has been developed to counter this virus, the only way the human race can tackle this situation is by testing. If the presence of COVID-19 is detected early, then there 


\section{Advanced Materials Letters www. vbripress.com/aml}

are higher chances of the patient overcoming this dreadful virus. Therefore, it is really important that all the countries test heavily at this point of time.

Currently, PCR and immunoassay technologies are ideal for primary clinical decision. Correct diagnosis is must for final treatment. However, similar type coinfections or clinical phenotypes by other seasonal viruses such as influenza viruses and enteroviruses can make diagnosis complicated. The pandemic situation has been generated due to breaking of the barriers related to populations, regions, and environment. In such instances, misidentification or false positive results can affect proper treatment. The advanced genomics is helpful in point-ofcare real-time RT-PCR diagnostic tests, as it's based on the genomic sequence of $\mathrm{CoV}$. The genetic database is helpful in comparison and establishing link with other similar pathogens. The early detection of COVID-19 is critical to isolate confirmed cases and prevent further transmission [25]. Typically, it will reduce the time spent in isolation process. The study from swab samples in the epidemic area of China shows that chest CT had higher sensitivity for diagnosis of COVID-19 as compared with initial reverse-transcription polymerase chain reaction (RT-PCR) [26]. To avoid disease spreading, there is urgent need to shift research funding for diagnosis based on technologies, which can work with advanced genomics of pathogen and host interactions. Gene-environment interaction is an important aspect, which can cover emerging trend of pathogens and their pathogenicity. To understand the disease mechanism, developing fluorescent based real-time PCR kit is also useful to get results rapidly. Several test kits to detect monoclonal and polyclonal antibodies against COVID-19 in patients are important to detect the virus.

The important guidelines regarding methodology, epidemiological characteristics, disease screening, population prevention, diagnosis, treatment and control for the COVID-19 must be followed [27]. The diagnostics company Cepheid declared that it has received emergency authorization from the U.S. Food and Drug Administration (FDA) to use its rapid molecular test for point-of-care patients that can detect the virus that causes COVID-19 in 45 minutes [28]. The U.K. recently announced a $£ 46$ million aid package to fight the new coronavirus, including funding for a rapid diagnostic test and assisting health system preparation in vulnerable countries [29]. All the above-mentioned fast track-based initiatives are important to combat COVID-19 effectively.

\section{Need of the Hour: Worldwide efforts for successful treatment}

WHO announced a large global trial of the potential drugs for COVID-19 [30]. Several drugs, which received significant attention in many countries against the dangerous COVID-19 were used for effective treatment. The drug remdesivir stops viral replication by inhibiting a key viral enzyme, the RNA-dependent RNA polymerase, found to be one of hope in case report of COVID-19 [31].

Likewise, drugs chloroquine and hydroxychloroquine work by decreasing the acidity in endosomes, compartments inside cells that they use to ingest outside material and that some viruses can coopt to enter a cell. Researchers in China have published a study in which they treated COVID-19 patients with chloroquine [32]. French researchers also reported treating effectively with hydroxychloroquine [33]. Lopinavir inhibit the protease of HIV, an important enzyme that cleaves a long protein chain into peptides during the assembly of new viruses. The combination of drugs (Ritonavir/lopinavir), was also one option to treat COVID-19 [34].

\section{How long until we develop the COVID-19 vaccine?}

There are many vaccines in developmental stage across the world. In fact, one is under human trials. Vaccine development is related to animal than human trials to understand its efficacy for the safety and protection. Due to various human variant of coronaviruses and diversified affected populations, it is challenging to make it compatible for various populations of different continents. Various vaccines are either in $1^{\text {st }}$ stage or waiting for human trial in coming months. The first dose of the mRNA-1273 coronavirus vaccine, developed by the US National Institutes of Health (NIH) and Moderna's infectious disease research team, was given to the first participant in their phase 1 study on March 16, 2020 [35].

Authorities in China granted approval last week for phase 1 clinical trials of a coronavirus vaccine developed by researchers at Tianjin-based CanSino Biologics and the Academy of Military Medical Sciences. Pennsylvaniabased INOVIO announced the receipt of a new $\$ 5$ million grant from the Bill \& Melinda Gates Foundation on March 12, 2020 to accelerate the testing of its novel DNA vaccine for COVID-19, known as INO-4800 [35]. The European Commission has offered up to $€ 80$ million of financial support to CureVac, which plans to launch clinical tests in June 2020. German immunotherapy company BioNTech and American pharma giant Pfizer codevelop and distribute an mRNA-based vaccine against the novel coronavirus.

Another method is known as Plasma Therapy in which plasma of the recovered patient containing the antibodies that can fight against COVID-19 will be transferred to the body of the person who is struggling to develop their own antibodies [36]. This process for COVID-19 is also still under trial but the Chinese doctors have claimed and published their research according to which they were able to treat 7 out of 10 patients successfully using Plasma Therapy. Thus, the doctors of Britain and America have also started trials using Plasma Therapy. This therapy will only act as a stopgap measure until better treatment or vaccine is available. 


\section{Advanced Materials Letters www. vbripress.com/aml}

\section{Adaptation of hygiene}

Ensuring the hygienic travel and transport is important for controlling any epidemic situation and stop it to become pandemic. In various infectious diseases, not only diseased but also asymptomatic persons play key role in disease transmission. So, health authorities should establish the best healthcare practices for person's disease carrier screening and document it in the health passport or other biological testing system and tools, which cover long term health history. This kind of adaptation will be helpful for defined decision for travel, which can be conducted through certain guidelines and ensure zero risk to others.

\section{Identification of risk models}

Controlling the disease transmission from one country to another is one of the key policies, which ensures to stop disease spreading within community or in countries. Specifically, transmission associated with public mobility such as travel, tourism, religious gathering spread more with the help of regional mobility, which further becomes dangerous due to community transmission. Therefore, it's important to work in dual frame of travel transmission in which one part is focused on international hygiene for travelers safety purposes, while another part is focused on stopping regional travels, where mobility was stopped for a while and start community based preventive healthcare management. Therefore, global lockdown and stay at home are the best prevention practices for COVID-19.

\section{Initiative of scientific world}

In the pandemic situation, scientific world has stimulated the process and management of rapid publication for knowledge sharing and research promotion through funding opportunities. In publication field, publishers have made coronavirus (COVID-19) content freely available and reusable. More than 30 leading publishers have committed to making all of their COVID-19 and coronavirus-related publications, and the available data supporting them, immediately accessible in PubMed Central (PMC) and other public repositories [37]. Elsevier has developed "Novel Coronavirus Information Center", where you will find expert, curated information for the research and health community on COVID-19. All resources are free to access and include guidelines for clinicians and patients [38].

The leading research funding organizations, NGOs, etc. are deeply concerned for the COVID-19 pandemic situation and have opened funding opportunities for public health. Table 2 refers to various funding opportunities and data sharing information by world leading organizations.

In the current scenario, International Association of Advanced Materials (IAAM) has encouraged R\&D consortium on COVID-19 by creating multi-lateral cooperation in the area of 'digital healthcare innovation and technology'.
Table 2. Appreciable and timely contribution of world-leading organizations for research and data sharing on COVID-19.

\begin{tabular}{|c|c|c|c|}
\hline $\begin{array}{l}\text { Funding } \\
\text { Category }\end{array}$ & Name of call & $\begin{array}{l}\text { Funding } \\
\text { agency }\end{array}$ & Ref. \\
\hline$R \& D$ & $\begin{array}{l}\text { Coronavirus Disease } 2019 \\
\text { (COVID-19) }\end{array}$ & $\mathrm{NIH}, \mathrm{USA}$ & [39] \\
\hline $\mathrm{R} \& \mathrm{D}$ & $\begin{array}{l}\text { Urgent Competitive Revisions } \\
\text { for Research on the } 2019 \text { Novel } \\
\text { Coronavirus (2019-nCoV) }\end{array}$ & $\begin{array}{l}\text { NIAID and } \\
\text { NIGMS, } \\
\text { USA }\end{array}$ & {$[40]$} \\
\hline$R \& D$ & $\begin{array}{l}\text { Development of therapeutics } \\
\text { and diagnostics combatting } \\
\text { coronavirus infections }\end{array}$ & $\begin{array}{l}\text { European } \\
\text { Commission }\end{array}$ & [41] \\
\hline $\mathrm{R} \& \mathrm{D}$ & $\begin{array}{l}\text { RAPID Research on } \\
\text { Coronavirus (COVID-19) }\end{array}$ & NSF, USA & {$[42]$} \\
\hline$R \& D$ & $\begin{array}{l}\text { Rapid Response Call for novel } \\
\text { coronavirus research }\end{array}$ & $\begin{array}{l}\text { UKRI, } \\
\text { United } \\
\text { Kingdom }\end{array}$ & [43] \\
\hline $\mathrm{R} \& \mathrm{D}$ & $\begin{array}{l}\text { Novel Coronavirus (COVID- } \\
\text { 19) Rapid Research Funding } \\
\text { Opportunity }\end{array}$ & $\begin{array}{l}\text { CIHR, } \\
\text { Canada }\end{array}$ & [44] \\
\hline $\mathrm{R} \& \mathrm{D}$ & $\begin{array}{l}\text { Rapid support for research into } \\
\text { coronaviruses and their impact }\end{array}$ & $\begin{array}{l}\text { SNF, } \\
\text { Switzerland }\end{array}$ & {$[45]$} \\
\hline $\mathrm{R} \& \mathrm{D}$ & $\begin{array}{l}\text { Fast-tracking research into } \\
\text { treatments for COVID-19 }\end{array}$ & $\begin{array}{l}\text { Health } \\
\text { Ministry, } \\
\text { Australia }\end{array}$ & {$[46]$} \\
\hline $\mathrm{R} \& \mathrm{D}$ & $\begin{array}{l}\text { Initiative to Speed Development } \\
\text { and Access to Therapies for } \\
\text { COVID-19 }\end{array}$ & $\begin{array}{l}\text { Bill \& } \\
\text { Melinda } \\
\text { Gates } \\
\text { Foundation }\end{array}$ & [47] \\
\hline $\mathrm{R} \& \mathrm{D}$ & Fund for social cause & $\begin{array}{l}\text { Seattle } \\
\text { Foundation }\end{array}$ & {$[48]$} \\
\hline $\begin{array}{l}\text { Data } \\
\text { sharing }\end{array}$ & $\begin{array}{l}\text { Novel Coronavirus Information } \\
\text { Center }\end{array}$ & Elsevier & [49] \\
\hline $\begin{array}{l}\text { Data } \\
\text { sharing }\end{array}$ & $\begin{array}{l}\text { Sharing research data and } \\
\text { findings relevant to the novel } \\
\text { coronavirus (COVID-19) } \\
\text { outbreak }\end{array}$ & $\begin{array}{l}\text { Wellcome } \\
\text { Trust }\end{array}$ & {$[\mathbf{5 0}]$} \\
\hline $\mathrm{R} \& \mathrm{D}$ & Fighting COVID-19 & TDB/DST & {$[51]$} \\
\hline $\mathrm{R} \& \mathrm{D}$ & $\begin{array}{l}\text { CSIR-NMITILI Proposal on } \\
\text { Coronavirus }\end{array}$ & CSIR & {$[52]$} \\
\hline
\end{tabular}

\section{Multi-end Consortium on COVID-19}

International Association of Advanced Materials (IAAM) had organized the $4^{\text {th }}$ edition of 'Translational Research \& Innovation Symposium' with the theme: 'Translational Research and Innovation for Healthcare Technology' on 10 February 2020 at VBRI Innovation Centre, New Delhi, India (Fig. 2) [53]. The aim of this edition was to create consortium in the area of advanced research $\&$ innovation for digital medicine. This consortium had run with two sessions, where $1^{\text {st }}$ session covered 11 important keynotes, invited and innovative talks. Then, the $2^{\text {nd }}$ session had translational research and technology cooperation consortium for coronavirus research. This consortium was focused on current epidemic of a novel coronavirus affecting China, along with reported cases in 27 other countries at that time. Further it was assuming to spread beyond border across other continents, so making strategy in advance was one of the timely initiatives for prevention methods. This meeting brought together interdisciplinary 


\section{Advanced Materials Letters www. vbripress.com/aml}

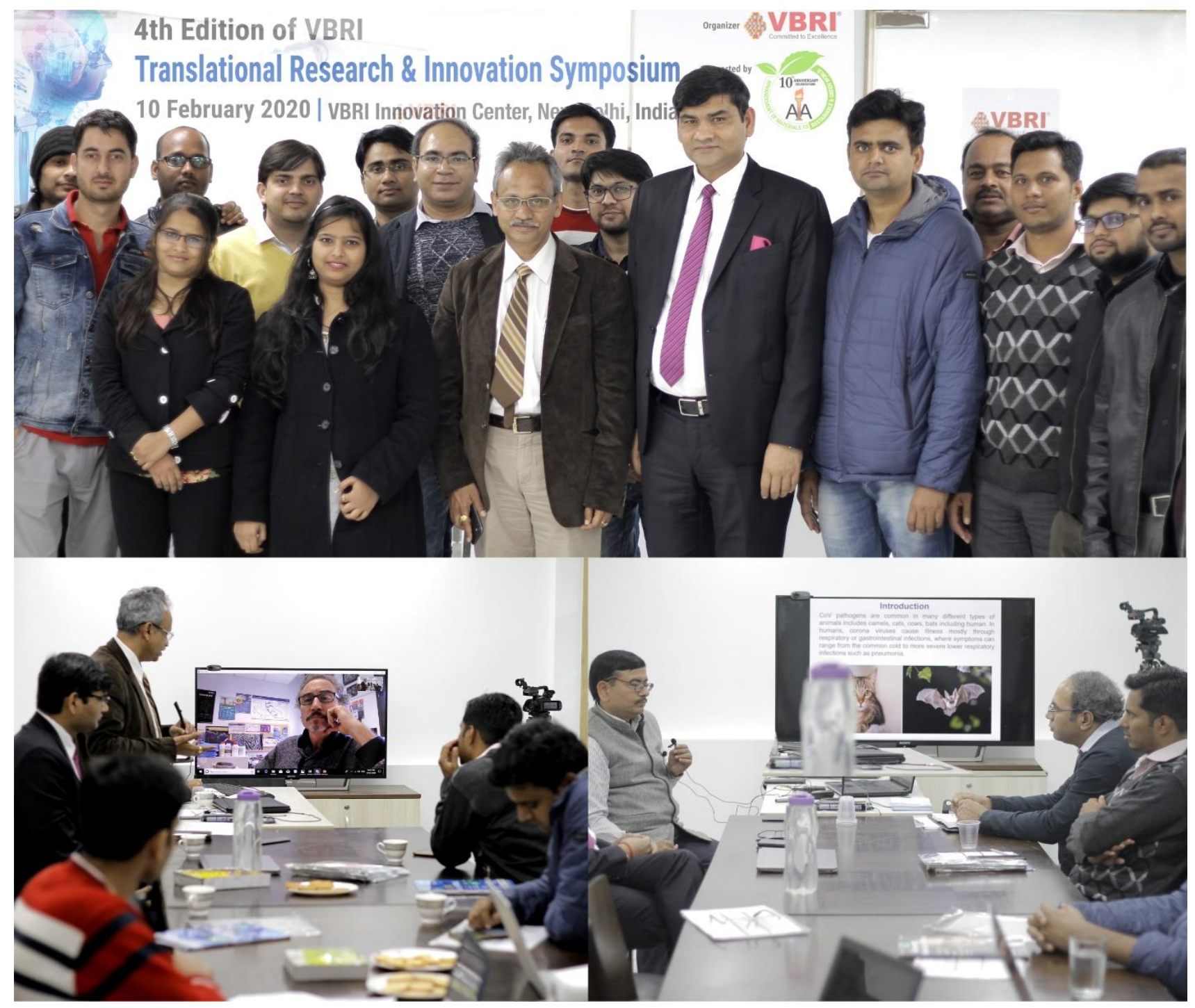

Fig. 2. Consortium to combat epidemic Coronavirus disease using digital medicine at VBRI Innovation Center, New Delhi, India.

scientists working in several fields like healthcare, biotechnology, IT, computational, nanotechnology, medicine, and chemical engineering for exchange of ideas and recognized effective research and technology for a healthy tomorrow. It was intended to form a network of collaboration for the utilization of various interdisciplinary scientific experts and valid healthcare solutions based on digital medicine were also presented. Finally, the scientists of consortium believed that the applications of integrated technology system will be transferrable to virus infected multiple hosts system including human as preferable.

\section{Future prospects}

The recent and future challenges of various virus species, due to complex diagnosis and ineffective control mechanisms, have attributed negative impact on human health [54]. The threat posed by COVID-19, can be overcome if as the $1^{\text {st }}$ step, countries can identify, isolate, and treat cases immediately. At the same time, as the $2^{\text {nd }}$ step, stopping population mobility and tracing asymptomatic cases is very important, as handful of cases can become source of community transmission. China and South Korea have demonstrated that this virus can be suppressed and controlled through better and timely healthcare management.

Efforts based on multilateral and multi-disciplinary approaches may lead to development of effective technology. Further, technology development will be continued together with our existing experiences gained with the sixth phase of a field trial of the mHospitals [5558], cardiac cloud care at home. mHospitals is a revolutionary virtual hospital that utilizes cloud medicine, machine learning, and artificial intelligence to provide the best quality of cardiac care along with the ultimate convenience. This kind of integrated approaches with biotechnology models may bring better solutions for current coronavirus challenges. 


\section{Advanced Materials Letters www. vbripress.com/aml}

\section{Conclusion}

Virus infection globally affects the human health and is considered a limiting factor for further sustainable development. This editorial extensively highlights important technology parameters which can be used for effective prognosis and control strategies. VBRI demonstrated the preventive and prognosis model for coronavirus epidemic using AI-enabled wireless medicine. This model came to an end with the advanced technology through experts laying emphasis on the need and efforts of VBRI to form a multi-ends international alliance to develop world-class healthcare solutions based on AI and ML digital medicine. VBRI is committed to establishing parallel wireless healthcare technology, for the benefit of mankind. The consortium of coronavirus will be conducted to make worldwide network for sharing knowledge and technology beyond boundaries to combat all kinds of coronavirus challenges more effectively.

\section{Acknowledgements}

This research was funded by the VBRI and Institute of Advanced Materials, IAAM, Sweden.

\section{Conflict of interest}

All authors declare that they have no conflict of interest.

\section{Keywords}

Coronavirus, COVID-19, infectious disease, medical technology, healthcare management.

\section{References}

1. Huang, C.; Wang, Y.; Li, X.; Ren, L.; Zhao, J.; et al., Lancet, 2020 , 395, 497

2. Zhu, N.; Zhang, D.; Wang, W.; Li, X.; Yang, B.; et al., N. Engl. J. Med., 2020, DOI: 10.1056/NEJMoa2001017.

3. Cui, J.; Li, F.; Shi, Z.L.; Nat Rev Microbiol., 2019, 17, 181-192.

4. Killerby, M.E.; Biggs, H.M.; Midgley, C.M.; Gerber, S.I.; Watson, J.T.; Emerg. Infect. Dis., 2020, 26, 191-198.

5. Gupta, S.; Tiwari, A.; Jain, U.; Chauhan, N.; Mater. Sci. Eng. C, 2019, 103, 109733.

6. Ashaduzzaman, M.; Deshpande, S.R.; Murugan, N.A.; Mishra, Y.K.; Turner, A.P.F; Tiwari, A.; Sci. Rep., 2017, 7, 44027.

7. Parlak, O.; Turner, A.P.F.; Tiwari, A.; J. Mater. Chem. B, 2015, 3, 7434-7439.

8. Tiwari, A.; Adv. Mater. Lett., 2019, 10, 79-79.

9. Hui, D.S.; J. Thorac. Dis., 2013, 5 S122-S126.

10. "Middle East respiratory syndrome coronavirus (MERS-CoV)", viewed 03 April 2020, <https://www.who.int/emergencies/merscov/en/>.

11. "Infection prevention and control during health care when novel coronavirus (nCoV) infection is suspected", viewed 03 April 2020, $<$ https://www.who.int/publications-detail/infection-prevention-andcontrol-during-health-care-when-novel-coronavirus-(ncov)infection-is-suspected-20200125>.

12. Kim, K.H.; Tandi, T.E.; Choi, J.W.; Moon, J.M.; Kim, M.S.; J. Hosp. Infect., 2017, 95, 207-213.

13. "Coronavirus (COVID-19) map", viewed 03 April 2020, <https://www.google.com/covid19-map/>.

14. "COVID-19 Coronavirus Pandemic", viewed 03 April 2020, $<$ https://www.worldometers.info/coronavirus/>

15. Kaur, H.; Shorie, M.; Nanoscale Adv., 2019, 1, 2123

16. Cunha, I.; Biltes, R.; Sales, M.G.F.; Vasconcelos, V.; Sensors, 2018, 18, 2367.

17. Guan, Y.; Ackert-Bicknell, C.L.; Kell, B.; Troyanskaya, O.G.; Hibbs, M.A.; PLoS Comput. Biol., 2010, 6, e1000991.
18. Rozek, L.S.; Dolinoy, D.C.; Sartor, M.A.; Omenn, G.S.; Annu. Rev. Public Health, 2014, 35, 105-122.

19. He, J.; Baxter, S.L.; Xu, J.; et al., Nat. Med., 2019, 25, 30-36.

20. "WHO Technical Report, Series No. 924, 2004", viewed 03 April 2020 ,

<https://www.who.int/bloodproducts/publications/WHO_TRS_924 _A4.pdf $>$

21. "Virus Removal by Filtration: Points to Consider" https://www.biopharminternational.com/virus-removal-filtrationpoints-consider

22. Dichtelmuller, H.O.; Flechsig, E.; Sananes, F.; Kretschmar, M.; Dougherty, C.J.; Results Immunol., 2012, 2, 19-24

23. Tiwari, A.; Adv. Mater. Lett., 2019, 10, 302-302.

24. Elenko, E.; Underwood, L.; Zohar, D.; Nat Biotechnol., 2015, 33, 456-461.

25. Amrane, S.; Tissot-Dupont, H.; Doudier, B.; Eldin, C.; Hocquart, M; et al. Travel Med. Infect. Dis. 2020, 101632.

26. Ai, T.; Yang, Z,; Hou, H.; Zhan, C.; Chen, C.; Radiology, 2020.

27. Jin, Y.; Cai, L.; Cheng, Z.; et al. Military Med. Res. 2020, 7, 4.

28. 'FDA grants 'emergency use' coronavirus test that can deliver results in 45 minutes", viewed 03 April 2020, <https://www.cnbc.com/2020/03/21/fda-grants-emergency-usecoronavirus-test-that-can-deliver-results-in-45-minutes.html>

29. "UK government to fund coronavirus rapid diagnostic test", viewed 03 April 2020, <https://www.devex.com/news/uk-government-tofund-coronavirus-rapid-diagnostic-test-96712>

30. "WHO R\&D Blueprint COVID-1 Informal consultation on the potential role of chloroquine in the clinical management of COVID 19 infection", viewed 03 April 2020,

<https://www.who.int/blueprint/priority-diseases/key-action/RDBlueprint-expert-group-on-CQ-call-Mar-13-2020.pdf?>

31. Michelle, L.; Holshue, C.D.B.; Lindquist, S.; Lofy, K.H.; Wiesman, J.; N. Engl. J. Med. 2020, 382, 929-936.

32. Gao, J.; Tian, Z.; Yang, X.; BioScience Trends., 2020, 14, 72-73.

33. Gautreta, P.; Lagiera, J.-C.; Parola, P.; Hoanga, V.T.; Meddeba, L.; et al., Int. J. Antimicrob. Agents, 2020.

34. Cao, B.; Wang, Y.; Wen, D.; Liu, W.; Wang, J.; et al.; N. Eng. J. Med., 2020.

35. "WHO launches global megatrial of the four most promising coronavirus treatments", viewed 03 April 2020,

<https://www.sciencemag.org/news/2020/03/who-launches-globalmegatrial-four-most-promising-coronavirus-treatments $>$.

36. "Houston hospital first in US to try coronavirus blood transfusion therapy"

$<\mathrm{https}: / /$ economictimes.indiatimes.com/news/international/worldnews/houston-hospital-first-in-us-to-try-coronavirus-bloodtransfusion-therapy/>

37. "Publishers make coronavirus (COVID-19) content freely available and reusable", viewed 03 April 2020 ,

$<$ https://wellcome.ac.uk/press-release/publishers-makecoronavirus-covid-19-content-freely-available-and-reusable>

38. "Novel Coronavirus Information Center", viewed 03 April 2020 $<$ https://www.elsevier.com/connect/coronavirus-informationcenter>

39. "Coronavirus Disease 2019 (COVID-19): Information for NIH Applicants and Recipients of NIH Funding" viewed 03 April 2020, <https://grants.nih.gov/grants/natural_disasters/corona-virus.htm>

40. "Notice of Special Interest (NOSI) regarding the Availability of Urgent Competitive Revisions for Research on the 2019 Novel Coronavirus (2019-nCoV)", viewed 03 April 2020,

$<$ https://grants.nih.gov/grants/guide/notice-files/NOT-AI-20030.html>

41. "Development of therapeutics and diagnostics combatting coronavirus infections", viewed 03 April 2020, $<$ https://ec.europa.eu/info/fundingtenders/opportunities/portal/screen/opportunities/topic-details/imi22020-21-01>

42. "Coronavirus Information", viewed 03 April 2020, <https://www.nsf.gov/news/special_reports/coronavirus/>

43. "Rapid Response Call for novel coronavirus research", viewed 03 April 2020, <https://esrc.ukri.org/funding/funding-opportunities/ 2019-ncov-rapid-response-call/ 


\section{Advanced Materials Letters www. vbripress.com/aml}

44. "Canadian 2019 Novel Coronavirus (COVID-19) Rapid Research Funding Opportunity Results", viewed 03 April 2020, <https://cihrirsc.gc.ca/e/51908.html>

45. "Special Call on Coronaviruses" viewed 03 April 2020, $<$ http://www.snf.ch/en/funding/programmes/coronavirus/Pages/def ault.aspx>

46. "Fast-tracking research into treatments for COVID-19", viewed 03 April 2020, <https://www.health.gov.au/ministers/the-hon-greghunt-mp/media/fast-tracking-research-into-treatments-for-covid19>

47. "COVID-19 Updates", viewed 03 April 2020, <https://www.gatesfoundation.org/TheOptimist/coronavirus>

48. "The COVID-19 Response Fund is rapidly deploying resources to community-based organizations that are supporting local workers and families most affected by the coronavirus crisis", viewed 03 April 2020,

<https://www.seattlefoundation.org/communityimpact/civicleadership/covid-19-response-fund>

49. "Novel Coronavirus Information Center", viewed 03 April 2020, <https://www.elsevier.com/connect/coronavirus-informationcenter>

50. "Sharing research data and findings relevant to the novel coronavirus (COVID-19) outbreak" viewed 03 April 2020, <https://wellcome.ac.uk/press-release/sharing-research-data-andfindings-relevant-novel-coronavirus-covid-19-outbreak>

51. "Fight COVID-19" viewed 03 April 2020, <http://tdb.gov.in/ wpcontent/uploads/2020/03/TDB-advt_16x25-Eng-New2.pdf>

52. "CSIR-NMITILI Proposal on Coronavirus", viewed 03 April 2020, <https://www.csir.res.in/opprotunity/special-call-proposals-indianindustryies-corona-virus-under-csir-nmitli-programme-last>

53. "John Hopkins University and Medicine Coronavirus Resource Centre", viewed 03 April 2020,

<https://coronavirus.jhu.edu/map.html>.

54. "mHospitals" viewed 03 April 2020,

< https://www.mhospitals.com/>.

55. "New dawn in healthcare: 'mHospitals' app launched in 3 countries", viewed 03 April 2020,

$<$ https://www.hindustantimes.com/cities/new-dawn-in-healthcaremhospitals-app-launched-in-3-countries/storyB6CXsRDAC9apZlbKmdLkSK.html>.

56. "VBRI mHospitals to facilitate cloud medicine for mass healthcare in India", viewed 03 April 2020,

<http://pharmabiz.com/NewsDetails.aspx ?aid=118541\&sid=2>.

57. "mHospitals intends to facilitate cloud medicine for mass healthcare", viewed 03 April 2020,

$<$ https://www.healthcareradius.in/technology/24635-mhospitalsintends-to-facilitate-cloud-medicine-for-mass-healthcare>.

58. "mHospitals are being launched in several countries - expected to meet 500 cardiac consultations in 90 days", viewed 03 April 2020, <https://www.electronicsworld.co.uk/mhospitals-are-beinglaunched-in-several-countries-expected-to-meet-500-cardiacconsultations-in-90-days/13236/>. 